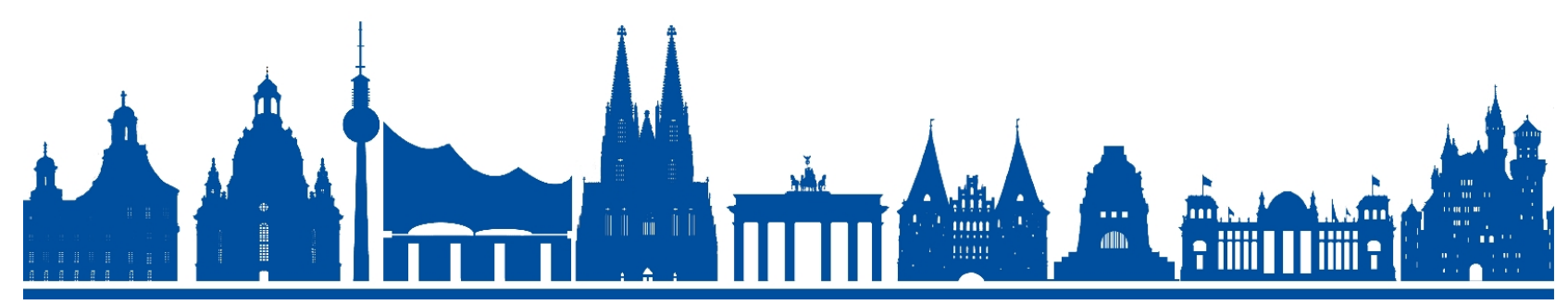

\title{
German Constitutional Court considers self-defence against non-State actors a tenable interpretation of Article 51 of the UN Charter
}

gpil.jura.uni-bonn.de/2019/10/german-constitutional-court-considers-self-defence-against-non-state-actors-atenable-interpretation-of-article-51-of-the-un-charter

Published: 10 October 2019 Author: Stefan Talmon

In an Order, dated 17 September 2019, the Second Senate of the Federal Constitutional Court dismissed as inadmissible an application brought by a parliamentary opposition group in the German Bundestag seeking a declaration that, by approving the deployment of German armed forces to prevent and suppress terrorist acts committed by the socalled "Islamic State" (ISIL), the Federal Government and the Bundestag had violated the German Constitution. In its decision the Federal Constitutional Court also addressed the question of self-defence against non-State actors.

Following the terrorist attacks in Paris on 13 November 2015, the Federal Government on 1 December 2015 authorised the deployment of up to 1,200 soldiers of the German armed forces to prevent and suppress terrorist acts committed by the terrorist organisation ISIL. The Federal Government invoked, inter alia, the right to collective selfdefence under Article 51 UN Charter and Security Council Resolution 2249 (2015) of 20 November 2015 as legal basis in international law for the deployment.

The German Bundestag approved the deployment in its decision of 4 December 2015. The Bundeswehr deployment, named "Operation Counter Daesh", began on 6 December 2015 with the German Navy providing protection for the French aircraft carrier Charles de Gaulle. In addition, the Bundeswehr provided Tornado reconnaissance aircraft, aircraft for air-to-air refuelling of fighter jets of the international alliance "Operation Inherent Resolve" in Iraq and Syria and personnel in command posts and headquarters as well as on board NATO's AWACS surveillance aircraft.

By letter of 10 December 2015, Germany notified the United Nations Security Council that it exercised its right of self-defence against ISIL under Article 51 UN Charter and specified that the actions were not directed against Syria. In the letter, Germany stated: 
"In accordance with Article 51 of the Charter of the United Nations, I report to the Security Council on behalf of my Government that the Federal Republic of Germany, in the exercise of the right of collective self-defence, has initiated military measures against the terrorist organization Islamic State in Iraq and the Levant (ISIL). These measures are directed against ISIL, not against the Syrian Arab Republic.

The Security Council has confirmed in its resolution 2249 (2015) of 20 November 2015 that ISIL "constitutes a global and unprecedented threat to international peace and security" and has called upon Member States to eradicate the safe haven that ISIL has established in significant parts of Iraq and the Syrian Arab Republic. ISIL has carried out, and continues to carry out, armed attacks against Iraq, France, and other States. These States have acted, and continue to act, by taking measures of self-defence.

ISIL has occupied a certain part of Syrian territory over which the Government of the Syrian Arab Republic does not at this time exercise effective control. States that have been subjected to armed attack by ISIL originating in this part of Syrian territory, are therefore justified under Article 51 of the Charter of the United Nations to take necessary measures of self-defence, even without the consent of the Government of the Syrian Arab Republic. Exercising the right of collective selfdefence, Germany will now support the military measures of those States that have been subjected to attacks by ISIL."

The applicant sought a declaration that, by approving the deployment of German armed forces on the basis of Article 51 of the UN Charter, the Federal Government and the Bundestag violated the Constitution. The applicant argued, inter alia, that the deployment exceeded the limits of the Act of Accession of the Federal Republic of Germany to the Charter of the United Nation as the deployment at issue contravened the purposes, structure or fundamental principles of the United Nations and, in particular, that the right of self-defence under Article 51 of the UN Charter did not cover operations carried out against non-State actors in the territory of a third State to which the actions of these nonState actors could not readily be attributed. The applicant asserted that such a broad interpretation of the right of self-defence was not part of Article 51 of the UN Charter.

Before the Federal Constitutional Court the Federal Government stated with regard to the legal basis for the deployment that 
"the Federal Republic of Germany supported France, Iraq and the international alliance in their fight against ISIL on the basis of the right of collective self-defence under Article 51 of the UN Charter. The Security Council had repeatedly stated that the terrorist organization ISIL constituted a threat to international peace and security. In its resolution 2249 (2015) of 20 November 2015, the Security Council had called upon the Member States to take action against ISIL. [...] Several allied and partner States of Germany had taken action against ISIL and had conducted military operations on Syrian territory in exercise of the right to individual and collective self-defence within the meaning of Article 51 of the UN Charter as the Syrian Government was unable and/or unwilling to prevent attacks from its territory by ISIL on Iraq in particular. Iraq had requested third-party intervention on the basis of Article 51 of the UN Charter. The action against ISIL in the exercise of the right of collective self-defence was covered by UN Security Council Resolution 2249 (2015)."

The Federal Constitutional Court was not called upon to decide on whether the Federal Government's interpretation of Article 51 of the UN Charter was correct but whether that interpretation was tenable. The Court stated:
"It does not matter whether the Federal Constitutional Court shares the international law assessment of the respondents on which the impugned action is based. Rather, the review is limited in principle to whether the assumptions are beyond what can be reasonably argued. The tenable interpretation of rights and obligations in a system [of collective security] and action within such a system, including in response to new security challenges, is the responsibility of the Federal Government and is generally within the scope of the authorisation granted by the act of approval to a treaty [here the Act of Accession of the Federal Republic of Germany to the Charter of the Unite Nations]."

Examining the justification for "Operation Counter Daesh", the Federal Constitutional Court held that the Government's understanding of the United Nations Charter, and Article 51 of the Charter in particular, was not untenable. The Court stated: 
“aa) The Security Council's call for action against ISIL and the subsequent actions of Member States serve the stated purpose of the United Nations 'to maintain international peace and security, and to that end: to take effective collective measures for the prevention and removal of threats to the peace' (Article 1(1) of the UN Charter). [...] [This is not about] a reorientation of the United Nations as a collective security system, but (only) about the pursuit of the peace and security objectives set out in the UN Charter in the face of the newly emerging phenomenon of an international terrorist organization with a consolidated territorial base.

bb) The structure of the United Nations is not affected by the military operation in question. The right to self-defence remains subject to the powers of the Security Council under Chapter VII of the UN Charter, even in case of operations in response to attacks by non-State actors with a consolidated territorial base in the territory of a third State. According to the second part of the first sentence of Article 51 of the UN Charter, recourse to the right of self-defence is precluded when the Security Council has taken the measures necessary to maintain international peace and security. In line with the basic structure of the collective security system of the Untied Nations, the Security Council thus retains the primary responsibility for the maintenance of international peace and security and can, at all times, take the necessary measures to restore international peace and thereby end the recourse to the right of individual or collective self-defence under international law.

cc) In its alternative claim, the applicant asserts that the limits of the Act of Accession to the UN Charter were exceeded given that the respondents provided an untenably broad interpretation of Article 51 of the UN Charter. Against this claim, it could already be argued that Security Council resolution 2249 (2015) could provide a sufficient basis for the deployment of the Bundeswehr so that there was no need to resort to Article 51 of the UN Charter. Against the background that the precise content of Article 51 of the UN Charter and a possible parallel rule in customary international law has never been without controversy but that the rule has been subject to various interpretation disputes since its inception, including its applicability to attacks by non-State actors, it is not evident that the criticized interpretation is untenably broad.

The wording of Article 51 of the UN Charter, in principle, does not preclude the inclusion of non-State actors as the authors of an armed attack. The wording also does not suggest a complete ban on adverse effects of acts of self-defence on other legal entities, such as States whose territory has become the consolidated base of operations of non-State actors. The broad interpretation of Article 51 of the UN Charter also does not contradict the object and purpose of the provision which ultimately guarantees the continuing ability of UN Member States to defend themselves against armed attacks, irrespective of the attacker, despite their obligation to fully respect the prohibition of the use of force. The fact that in the past such threats mainly emanated from inter-State conflicts only describes the historical conditions but does not necessarily limit the right of self-defence to attacks by State actors. It seems therefore at least arguable that attacks by non-State actors can be 
considered included in the right to self-defence, whose object and purpose is to allow an effective defence until the Security Council intervenes. The case-law of the International Court of Justice (ICJ) does not preclude such an interpretation. [...] The ICJ case-law, however, tended towards a more restrictive understanding of Article 51 of the UN Charter, according to which acts of self-defence directed at States in response to acts by non-State actors required that those acts could be attributed to the State concerned (cf. ICJ, Judgment of 27 June 1986 - Military and Paramilitary Activities in and against Nicaragua, Nicaragua v. United States of America -, ICJ Reports 1986, 14 at 64-65, para. 115; 103-104, para. 195; Advisory Opinion of 9 July 2004 - Legal Consequences of the Construction of a Wall in the Occupied Palestinian Territory -, ICJ Reports 2004, 136 at 194, para. 139). But, on the one hand, in the more recent case-law the ICJ has no longer committed itself to this understanding. On the other hand, the ICJ has yet to decide whether this restrictive understanding also applies if acts of self-defence under Article 51 of the UN Charter are not aimed at the State concerned but directly and only at a nonState actor having established itself on the territory of that State (in their separate opinions judges Kooijmans and Simma have considered it permissible to rely on the right to self-defence in such a situation, cf. ICJ, Judgment of 19 December 2005 Armed Activities on the Territory of Congo, Congo v. Uganda -, sep. op. Simma, ICJ Reports 2005, 334 at 337-338, paras.12-13, and sep. op. Kooijmans, ICJ Reports 2005, 306 at 313-314, paras. 25 et seq.; see also ICJ, Advisory Opinion of 9 July 2004 - Legal Consequences of the Construction of a Wall in the Occupied Palestinian Territory -, decl. Buergenthal, ICJ Reports 2004, 240 at 242-243, para. $6)$. In this case, the rights of the State are affected only by the fact that the territory where the acts of self-defence take place is part of its State territory, even though its exercise of governmental authority there is at best limited."

The decision of the Federal Constitutional Court calls for several observations. First, the Court's finding that the content of the right of self-defence under Article 51 of the UN Charter and, in particular, the question of whether it covered attacks by non-State actors had been controversial since the inception of the rule does not seem to be borne out by the facts. While there may have been sporadic examples of States claiming self-defence against non-State actors, the restrictive reading of the provision requiring that the armed attack comes from another State had been the generally accepted interpretation for more than 50 Years. It was only the terrorist attacks of September 11, 2001 which gave rise to an intensive debate on whether Article 51 also covers defensive measures against terrorist groups.

Second, while acknowledging that the decisions of the ICJ provide factual guidance beyond the particular case decided and serve as a source of international law pursuant to Article 38(1)(d) of the ICJ Statute, the Federal Constitutional Court departed from the existing case-law of the ICJ requiring an armed attack by one State against another, relying instead upon the separate opinions and declarations of individual judges who adopted a less restrictive interpretation of Article 51 of the UN Charter. However, even these judges made the right to self-defence against non-State actors subject to two conditions. The right of self-defence was to be triggered not by every kind of (terrorist) 
attack by non-State actors but only by "large-scale armed attacks". As the ICJ held in the Nicaragua case, only the "most grave forms of the use of force" constitute an armed attack. An armed attack by non-State actors exists only when force is used on a large scale, is of sufficient gravity and has a substantial effect. While ISIL's attacks on Iraq and Syria were undoubtedly of a scale and effect which would have been classified as an armed attack had it been carried out by regular armed forces, the legal situation with regard to the tragic terrorist attacks in Paris in November 2015 with 130 dead and several hundred injured is not as clear. Germany's claim that it supported France in its fight against ISIL on the basis of the right of collective self-defence under Article 51 of the UN Charter is thus at least debatable. The judges also required that the armed attacks were carried out from territory removed from the governmental authority of a State. While the Federal Constitutional Court did not address the first requirement, it based its findings on the fact that, at the relevant time, ISIL was an "international terrorist organization with a consolidated territorial base". In fact, in its Order the Court refers five times to the element of "a consolidated territorial base". Both the separate opinions of the ICJ judges and the order of the Constitutional Court thus do not provide any support for a right of selfdefence against ISIL beyond March 2019 when ISIL lost its last remnants of territorial control in Syria.

Third, the Federal Constitutional Court did not address the question of whether Germany was exercising the right to collective self-defence in conformity with the rules of customary international law. The individual ICJ judges relied upon by the Constitutional Court had pointed out in their separate opinions that the lawfulness of the conduct of the attacked State in the face of an armed attack by a non-State actor must be put to the same test as that applied in the case of self-defence against a State, namely, that the defensive action must be in conformity with the requirements of necessity and proportionality. Against the background that Iraq declared victory over ISIL and the complete liberation of Iraq from ISIL rule in December 2017, and that ISIL lost the last pocket of territory in Syria in March 2019 the incursion by German military aircraft into Syrian airspace and their reconnaissance activities inside Syria without the consent of the Syrian Government do no longer seem to be a suitable means to fight a potential terrorist threat posed by ISIL underground structures in Syria. In any case, the violation of the territorial integrity and political independence of Syria on a daily basis for almost four years seems grossly disproportionate to the professed aim of

The Federal Constitutional Court's contribution to the debate on the scope of the right to self-defence under Article 51 of the UN Charter is fairly limited. The Court held only that it was tenable to argue that the right of self-defence was applicable to attacks committed by non-State actors operating on the territory of another State. It did not find that it was tenable, or even correct, to argue that the military operations in Syria by Germany and other States could be justified on grounds of collective self-defence against ISIL. Not too much should thus be read into this decision.

Category: Use of force 
Prof. Dr. Stefan Talmon LL.M. M.A

Stefan Talmon is Professor of Public Law, Public International Law and European Union Law, and Director at the Institute of Public International Law at the University of Bonn. He is also a Supernumerary Fellow of St. Anne's College, Oxford, and practices as a Barrister from Twenty Essex, London. He is the editor of GPIL. 